\title{
Surface application of gypsum in low acidic Oxisol under no-till cropping system
}

\author{
Eduardo Fávero Caires ${ }^{1 *}$; Evandro Henrique Gonçalves Maschietto ${ }^{2}$; Fernando José \\ Garbuio $^{3}$; Susana Churka ${ }^{4}$; Hélio Antonio Wood Joris ${ }^{2}$ \\ ${ }^{1}$ UEPG - Depto. de Ciência do Solo e Engenharia Agrícola - Av. General Carlos Cavalcanti, 4748 - Campus \\ Uvaranas - 84030-900 - Ponta Grossa, PR - Brasil. \\ ${ }_{3}^{2} U E P G$ - Programa de Pós-Graduação em Agronomia. \\ ${ }^{3}$ Instituto Federal Catarinense - Rua das Rosas, Vila Nova - 88965-000 - Santa Rosa do Sul, SC - Brasil \\ ${ }^{4}$ USP/ESALQ - Programa de Pós-Graduação em Solos e Nutrição de Plantas, C.P. 9 - 13418-900 - Piracicaba, SP - Brasil. \\ *Corresponding author <efcaires@uepg.br>
}

\begin{abstract}
The conditions in which a favorable response to a gypsum application can be expected on crop yields are not clear. A 3-year field trial was carried out to evaluate the effects of gypsum application on soil chemical attributes and nutrition and yield of corn (Zea mays L.) and soybean (Glycine max L. Merrill) on a clayey Typic Hapludox of high fertility and low acidity under no-till in Guarapuava, Parana State, Brazil. Treatments were arranged in a randomized complete block design with four replications, and consisted of gypsum application on the soil surface at 4,8 , and $12 \mathrm{Mg} \mathrm{ha}^{-1}$. Gypsum application increased the $\mathrm{P}$ content in the soil most superficial layer $(0.0-0.1 \mathrm{~m})$ and also the exchangeable $\mathrm{Ca}$ and $\mathrm{S}-\mathrm{SO} 4^{2-}$ contents and the $\mathrm{Ca} / \mathrm{Mg}$ ratio in the soil profile $(0.0$ - $0.6 \mathrm{~m}$ ). Gypsum also caused leaching of $\mathrm{Mg}$ and $\mathrm{K}$ exchangeable in the soil. An increase in $\mathrm{Ca}$ concentrations in the corn leaves, and in $\mathrm{P}$ and $\mathrm{S}$ concentrations in the corn and soybean leaves occurred following the gypsum application. A yield response of corn to initial application of gypsum was found, but subsequent soybean crops did not respond. Gypsum application proved to be an effective practice to maximize no-till corn grain yield.
\end{abstract}

Key words: Zea mays, Glycine max, Brazil, phosphogypsum, calcium, sulfur

\section{Aplicação superficial de gesso num Latossolo de baixa acidez sob sistema plantio direto}

\begin{abstract}
RESUMO: Não estão claras as condições em que se podem esperar efeitos favoráveis da aplicação de gesso na produção das culturas. Em um experimento de campo avaliaram-se, durante três anos, os efeitos da aplicação de gesso nos atributos químicos de um Latossolo Vermelho argiloso de alta fertilidade e baixa acidez sob plantio direto e na nutrição e produção de milho (Zea mays L.) e soja (Glycine max L. Merrill), em Guarapuava (PR). Os tratamentos, dispostos em blocos completos ao acaso com quatro repetições, constaram da aplicação superficial de gesso nas doses 4, 8 e $12 \mathrm{Mg} \mathrm{ha}^{-1}$. A aplicação de gesso aumentou a concentração de $\mathrm{P}$ na camada mais superficial $(0.0-0,1 \mathrm{~m})$, bem como os teores de Ca trocável e de $\mathrm{S}_{-} \mathrm{SO}_{4}^{2-}$ e a relação $\mathrm{Ca} / \mathrm{Mg}$ no perfil do solo $(0.0-0,6 \mathrm{~m})$. A adição de gesso também ocasionou movimentação de $\mathrm{Mg}$ e $\mathrm{K}$ trocáveis no solo. A concentração de Ca nas folhas de milho e as concentrações de P e S nas folhas de milho e soja foram aumentadas com a aplicação de gesso. Houve aumento na produção de milho após aplicação de gesso, mas as culturas de soja subseqüentes não responderam ao gesso. A aplicação de gesso foi eficiente para maximizar a produção de grãos de milho no sistema plantio direto. Palavras-chave: Zea mays, Glycine max, Brasil, fosfogesso, cálcio, enxofre
\end{abstract}

\section{Introduction}

A no-till system (NT) with diversified crop rotations is an effective strategy to improve the sustainability of farming in tropical and sub-tropical regions. To control soil acidity in NT, lime is broadcasted on the soil surface without incorporation. Because surface liming is more effective in controlling acidity only at the soil most superficial layers (Ernani et al., 2004; Caires et al., 2005), management strategies have been developed to reduce acidity in the subsoil.

Gypsum is a by-product of the phosphoric acid industry which contains mainly calcium sulfate and small concentrations of phosphorous (P) and fluorine (F) and is largely available worldwide. Gypsum application on the soil surface followed by its leaching to acidic subsoils results in the improvement of root growth and higher absorption of water and nutrients by root plants (Sumner et al., 1986; Carvalho and van Raij, 1997).

Differences in crop responses to gypsum have been observed (Hammel et al., 1985; Caires et al., 1999); however, their causes are still unclear. In several field studies a gypsum application increased corn yields (Caires et al., 1999; Farina et al., 2000a; Caires et al., 2004), but not soybean yields (Quaggio et al., 1993; Oliveira and Pavan, 1996; Caires et al., 2003, 2006). Gypsum may increase crop yield due to increase of $\mathrm{Ca}$ and sulfate $\left(\mathrm{SO}_{4}{ }^{2-}\right)$ available to the plants (Caires et al., 2002, 2004). In a field trial conducted on an Oxisol under a NT, corn yield was increased by increasing the Ca saturation levels up to $56 \%$

Sci. Agric. (Piracicaba, Braz.), v.68, n.2, p.209-216, March/April 2011 
and by reducing the $\mathrm{Mg}$ saturation levels to about $12 \%$ in the soil surface layers (Caires et al., 2004). In addition, despite the $\mathrm{P}$ present in gypsum as an impurity is important for plant nutrition when high gypsum rates are applied this effect has often been neglected in studies with gypsum use (Sumner et al., 1986; Caires et al., 2003).

This study reports a field trial that examined the effects of gypsum application on soil chemical attributes and nutrition and yield of corn and soybean sowed on a NT established on an Oxisol of high fertility and low acidity. Because the cation exchange capacity of roots is lower in corn than in soybean (Fernandes and Souza, 2006) we hypothesize that (i) corn and soybean crops would present different responses to gypsum and (ii) the increase in crop grain yield with the gypsum addition is not associated only with amelioration of subsoil acidity conditions.

\section{Material and Methods}

The experiment was performed in Guarapuava, Paraná State, Brazil $\left(25^{\circ} 17^{\prime} \mathrm{S}, 51^{\circ} 48^{\prime} \mathrm{W}\right)$, on a dystrophic clayey Typic Hapludox. According to Köppen-Geiger System (Peel et al., 2007) the climate of this region is $\mathrm{Cfb}$, with mild summer and frequent frosts during the winter. Table 1 presents the results on chemical (Pavan et al., 1992) and particle-size distribution (EMBRAPA, 1997) analyses of the soil profile before the beginning of the experiment. Prior to the study, the field was used for grain cropping under a NT system for 15 years, with black oat (Avena strigosa Schreb) as the previous crop.

Treatments were arranged in a randomized complete block design with four replications and consisted of gypsum application at rates of 4,8 , and $12 \mathrm{Mg} \mathrm{ha}^{-1}$. Plot size was $49 \mathrm{~m}^{2}(7 \times 7 \mathrm{~m})$. Gypsum contained $205 \mathrm{~g} \mathrm{~kg}^{-1}$ of $\mathrm{Ca}$, $172 \mathrm{~g} \mathrm{~kg}^{-1}$ of sulfur (S), $2 \mathrm{~g} \mathrm{~kg}^{-1}$ of phosphorus (P) and $150 \mathrm{~g}$ $\mathrm{kg}^{-1}$ of moisture. Gypsum rates were calculated to raise the exchangeable calcium/magnesium $(\mathrm{Ca} / \mathrm{Mg})$ ratio of the topsoil $(0.0-0.2 \mathrm{~m})$, at values between 4 and 8 according to data from previous studies (Caires et al., 1999, 2004). Gypsum was applied on the soil surface on September 28, 2005. Between June 2005 and November 2007, the crop rotation was: black oat (Avena strigosa Schreb) (2005), corn (Zea mays L.) (2005 - 06), black oat (2006), soybean (Glycine max L. Merrill) (2006-07), black oat (2007), and soybean (2007 - 08).
Corn, hybrid P 30R50 was sown on October 07, 2005, at seeding rate of five seeds $\mathrm{m}^{-1}$ and row spacing of 0.75 $\mathrm{m}$. Fertilizers were applied at rates of $204 \mathrm{~kg} \mathrm{ha}^{-1}$ of nitrogen $(\mathrm{N})\left(42 \mathrm{~kg} \mathrm{ha}^{-1}\right.$ at sowing and $162 \mathrm{~kg} \mathrm{ha}^{-1}$ in topdressing), $102 \mathrm{~kg} \mathrm{ha}^{-1}$ of $\mathrm{P}_{2} \mathrm{O}_{5}$, and $120 \mathrm{~kg} \mathrm{ha}^{-1}$ of $\mathrm{K}_{2} \mathrm{O}$. Soybean, Magic cultivar, was sown on November 06, 2006, and November 24, 2007, at seeding rate of 10 seeds $\mathrm{m}^{-1}$ and row spacing of $0.4 \mathrm{~m}$. In 2006, soybean was sown without a fertilizer application and in 2007, $250 \mathrm{~kg} \mathrm{ha}^{-1}$ of a 2-20-20 complete fertilizer was applied at seeding. In both crops, soybean seeds were inoculated with Bradyrbizobium japonicum.

The monthly average data on rainfall and on maximum and minimum air temperature, registered during
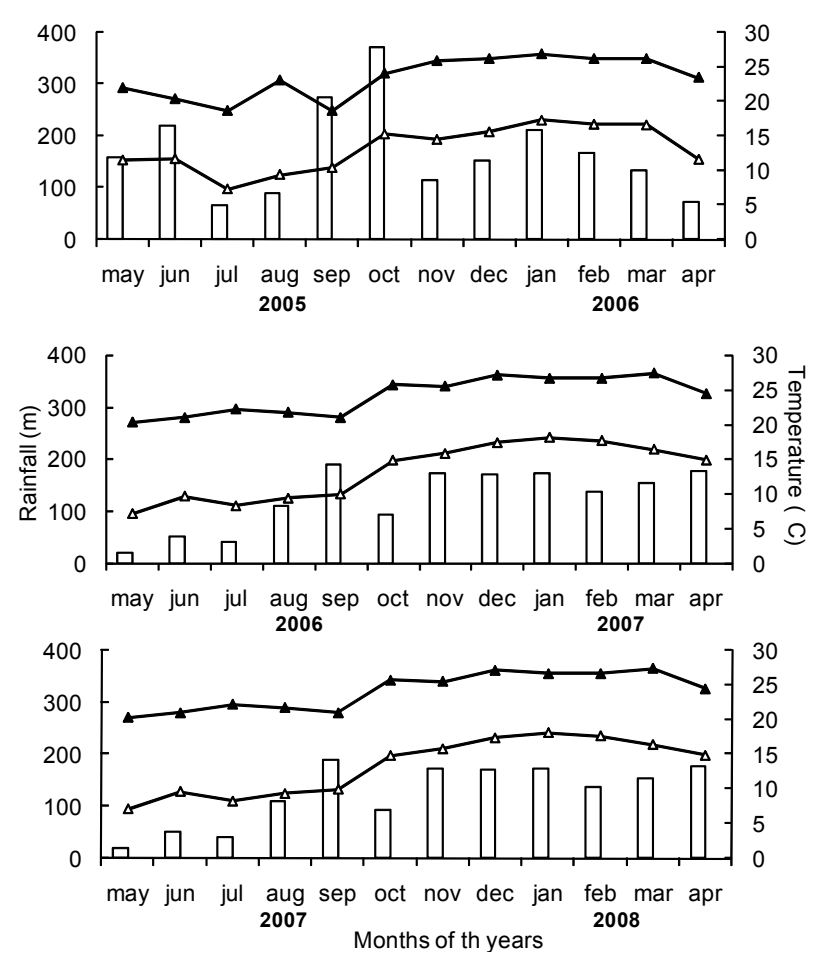

Figure 1 - Monthly rainfall (vertical bars) and maximum $(\mathbf{\Delta})$ andminimum $(\triangle)$ temperatures of the air, registered during the experiment (May 2005 to April 2008), in Guarapuava, PR.

Table 1 - Chemical and particle-size distribution analyses on soil samples at different depths, prior to initiation of the experiment in 2005.

\begin{tabular}{|c|c|c|c|c|c|c|c|c|c|c|c|c|}
\hline \multirow[b]{2}{*}{ Lay ers } & \multirow{2}{*}{$\begin{array}{l}\mathrm{pH} \text { in } \\
\mathrm{CaCl}_{2}\end{array}$} & \multicolumn{5}{|c|}{ Exchangeable cations } & \multirow[b]{2}{*}{ P (Mehlich-1) } & \multirow[b]{2}{*}{$\mathrm{C}$} & \multirow{2}{*}{$\begin{array}{c}\text { Base } \\
\text { saturation }\end{array}$} & \multirow[b]{2}{*}{ Sand } & \multirow[b]{2}{*}{ Silt } & \multirow[b]{2}{*}{ Clay } \\
\hline & & $\begin{array}{c}\mathrm{H}+ \\
\mathrm{Al} \\
\end{array}$ & $\mathrm{Al}$ & $\mathrm{Ca}$ & $\mathrm{Mg}$ & $\mathrm{K}$ & & & & & & \\
\hline $\mathrm{m}$ & & \multicolumn{5}{|c|}{$\mathrm{mmol}_{\mathrm{c}} \mathrm{dm}^{-3}$} & $\mathrm{mg} \mathrm{dm} \mathrm{m}^{-3}$ & $\mathrm{~g} \mathrm{dm}^{-3}$ & $\%$ & $\ldots$ & $\mathrm{g} \mathrm{kg}^{-1}$ & -1- \\
\hline $0.00-0.05$ & 6.1 & 36.9 & 0 & 55 & 28 & 4.8 & 6.3 & 36 & 70 & 80 & 320 & 600 \\
\hline $0.05-0.10$ & 5.9 & 42.8 & 0 & 48 & 24 & 4.4 & 6.3 & 28 & 64 & 77 & 303 & 620 \\
\hline $0.10-0.20$ & 5.7 & 49.6 & 0 & 44 & 18 & 3.9 & 3.1 & 24 & 57 & 72 & 228 & 700 \\
\hline $0.20-0.40$ & 5.2 & 62.1 & 0 & 23 & 29 & 2.4 & 1.8 & 20 & 47 & 64 & 216 & 720 \\
\hline $0.40-0.60$ & 5.0 & 66.9 & 0 & 15 & 10 & 4.2 & 1.5 & 17 & 30 & 67 & 193 & 740 \\
\hline
\end{tabular}


the field experiment, are shown in Figure 1. The weather conditions were normal for the region. The rainfall distribution was appropriate throughout the period of development of the corn and soybean crops in the field.

During the flowering period of the corn (in the 200506 year) and soybean (2006-07) crops, leaves were collected from 30 plants (third leaf from the apices of the soybean plant and first leaf below and opposite to the corn ear) of each plot (Malavolta et al., 1997). These samples were rinsed in deionized water, dried in a forced-air oven at $60^{\circ} \mathrm{C}$ until constant mass, and ground in a Wiley-type mill to pass a $0.75-\mathrm{mm}$ screen. The concentrations of $\mathrm{N}$, $\mathrm{P}, \mathrm{K}, \mathrm{Ca}, \mathrm{Mg}$, and $\mathrm{S}$ were determined according to methods described by Malavolta et al. (1997).

Soil samples were collected after harvesting both the corn in 2006, and the soybean, in 2007 and 2008, at 9, 18, and 30 months after the gypsum application. Twelve soil core samples per plot were taken with a soil probe sampler to obtain a composite sample of the $0.0-0.1$ and 0.1 $-0.2 \mathrm{~m}$ depths, and five cores of the $0.2-0.4$ and $0.4-0.6$ $\mathrm{m}$ depths. The soil samples were air dried, sieved through $2 \mathrm{~mm}$ sieve and stored in permeable plastic bags.

Soil $\mathrm{pH}$ was measured in a $0.01 \mathrm{~mol} \mathrm{~L}^{-1} \mathrm{CaCl}_{2}$ suspension (1:2.5 $\mathrm{v} \mathrm{v}^{-1}$, soil/solution); exchangeable calcium (Ca), magnesium $(\mathrm{Mg})$ and potassium $(\mathrm{K})$, as well as phosphorus ( $\mathrm{P}$, by the Mehlich-1 method) were determined according to Pavan et al. (1992). In addition, the soil S-SO ${ }_{4}^{2-}$ contents were extracted with the solutions of calcium phosphate $0.01 \mathrm{~mol} \mathrm{~L}^{-1}$ (Cantarella and Prochnow, 2001) and ammonium acetate $0.5 \mathrm{~mol} \mathrm{~L}^{-1}$ in acetic acid $0.25 \mathrm{~mol} \mathrm{~L}^{-1}$ (Vitti and Suzuki, 1978), in a 1:2.5 $\left(\mathrm{v} \mathrm{v}^{-1}\right)$ soil/solution ratio.

Corn and soybean yields were evaluated after physiological maturation of the crops through manual harvesting. Corn grain was harvested from $12 \mathrm{~m}^{2}$ plots, and soybeans were harvested from $9.6 \mathrm{~m}^{2}$ plots. Grain yields were expressed at $130 \mathrm{~g} \mathrm{~kg}^{-1}$ moisture content.

Results were submitted to polynomial regression analyses. The criterion for choosing the regression model was the magnitude of the determination coefficients provided it was significant at $p<0.05$.

\section{Results and Discussion}

Surface-applied gypsum did not influence soil $\mathrm{pH}$, at the four soil depths analyzed. The average soil $\mathrm{pH}$ values $\left(0.01 \mathrm{~mol} \mathrm{~L}^{-1} \mathrm{CaCl}_{2}\right)$, after 9,18 , and 30 months of gypsum application, varied from 5.6 to 5.8 at $0-0.1 \mathrm{~m}$ depth, from 5.4 to 5.5 at $0.1-0.2 \mathrm{~m}$ depth, from 5.3 to 5.4 at $0.2-0.4 \mathrm{~m}$ depth, and from 5.0 to 5.2 at $0.4-0.6 \mathrm{~m}$ depth.

Because gypsum is a neutral salt that has no ability to consume protons $\left(\mathrm{H}^{+}\right)$, no effect of gypsum application on soil acidity was expected. However, gypsum application may increase the $\mathrm{pH}$ in the subsoil layers (Caires et al., 2002, 2003; Carvalho and van Raij, 1997) due to a reaction of ligand substitution on the surface of soil particles, involving $\mathrm{Fe}$ and $\mathrm{Al}$ hydrated oxides, $\mathrm{SO}_{4}{ }^{2-}$ displacing $\mathrm{OH}^{-}$, thus promoting a partial neutralization of soil acidity (Reeve and Sumner, 1972). Since in the present study, the $\mathrm{pH}\left(0.01 \mathrm{~mol} \mathrm{~L}^{-1} \mathrm{CaCl}_{2}\right)$ was $\geq 5.0$ throughout soil profile $(0.0-0.6 \mathrm{~m})$, exchangeable $\mathrm{Al}$ was not detected in the soil.

The content of exchangeable $\mathrm{Ca}$ has increased linearly in all soil depths proportionally to gypsum rates, after 9, 18 and 30 months of the application (Figure 2). Gypsum application caused leaching of exchangeable $\mathrm{Ca}$ in the soil profile over time, having registered the highest increment in the $\mathrm{Ca}$ content in the $0.0-0.1 \mathrm{~m}$ soil depth, after 9 months, and in the soil deepest layer $(0.4-0.6 \mathrm{~m})$, after 30 months. The movement of exchangeable $\mathrm{Ca}$ in the soil profile after the gypsum application may vary according to soil type, applied gypsum rate and volume of water applied. Quaggio et al. (1993) observed leaching of exchangeable $\mathrm{Ca}$ in the soil below the layer at $0.4-0.6 \mathrm{~m}$, after 18 months of the application of $6 \mathrm{Mg} \mathrm{ha}^{-1}$ of gypsum on an Oxisol under conventional tillage. Caires et al. (2001) verified that $80 \%$ of the exchangeable $\mathrm{Ca}$ in the soil had been leached to depths greater than $0.6 \mathrm{~m}$ after 64 months of the gypsum application at $12 \mathrm{Mg} \mathrm{ha}^{-1}$ on a loamy Oxisol under NT. In a trial conducted on a clayey Oxisol under NT, a gypsum application increased the exchangeable Ca content throughout the soil profile $(0.0-0.6 \mathrm{~m})$ with the greatest movement of exchangeable $\mathrm{Ca}$ be occurring under an application of gypsum at $9 \mathrm{Mg} \mathrm{ha}^{-1}$ after only 32 months (Caires et al., 2003). In a kaolinitic soil, in Georgia State (USA), there was a residual effect of the gypsum application at $35 \mathrm{Mg} \mathrm{ha}^{-1}$ on exchangeable Ca content up to $1.2 \mathrm{~m}$ soil depth, after 16 years (Toma et al., 1999).

Gypsum rates increased linearly the $\mathrm{Ca} / \mathrm{Mg}$ ratio in the soil, after 9, 18, and 30 months of the application, at the four soil depths studied (Figure 2); an exception was for the deepest layer $(0.4-0.6 \mathrm{~m})$, after 9 months. According to the adjusted regression equations, the highest gypsum rate $\left(12 \mathrm{Mg} \mathrm{ha}^{-1}\right)$ raised the $\mathrm{Ca} / \mathrm{Mg}$ ratio in the soil to $7.4(0.0-0.1 \mathrm{~m}), 3.5(0.1-0.2 \mathrm{~m})$, and $2.3(0.2-0.4 \mathrm{~m})$, after 9 months, and to 5.6 and $5.9(0.0-0.1 \mathrm{~m}), 2.9$ and 4.8 $(0.1-0.2 \mathrm{~m}), 2.3$ and $3.7(0.2-0.4 \mathrm{~m})$, and 2.0 and $4.3(0.4-$ $0.6 \mathrm{~m})$, respectively after 18 and 30 months. Gypsum application was able to increase the $\mathrm{Ca} / \mathrm{Mg}$ ratio in the soil $(0.0-0.2 \mathrm{~m})$ to values between 4 and 8 , reaching the target values mainly in the soil surface layer $(0.0-0.1 \mathrm{~m})$.

Exchangeable $\mathrm{Mg}$ content in the soil was reduced with the gypsum rates at $0.0-0.1 \mathrm{~m}$ depth, after 9 months, and at $0.0-0.1$ and $0.1-0.2 \mathrm{~m}$ depths, after 18 and 30 months (Figure 3). The leaching of exchangeable $\mathrm{Mg}$ from the most superficial soil layers resulted in an increase of this nutrient in the deepest layer $(0.4-0.6 \mathrm{~m})$, after 18 months of the gypsum application. This effect on subsoil was no longer observed 30 months after gypsum application, showing that gypsum rates resulted in the leaching of exchangeable $\mathrm{Mg}$ from the soil over time. The leaching of exchangeable $\mathrm{Mg}$ in the soil with a gypsum application is facilitated by the formation of the ionic pair $\mathrm{MgSO}_{4}{ }^{0}$ and it has been observed in several studies carried out under different conditions of soil and climate (Oliveira and Pavan, 1996; Caires et al., 1999; Toma et al., 1999; Farina et al., 2000b; Zambrosi et al., 2007). Thus, when gypsum is applied at high rates the loss of exchangeable $\mathrm{Mg}$ can be minimized by the use of dolomitic lime when correct- 


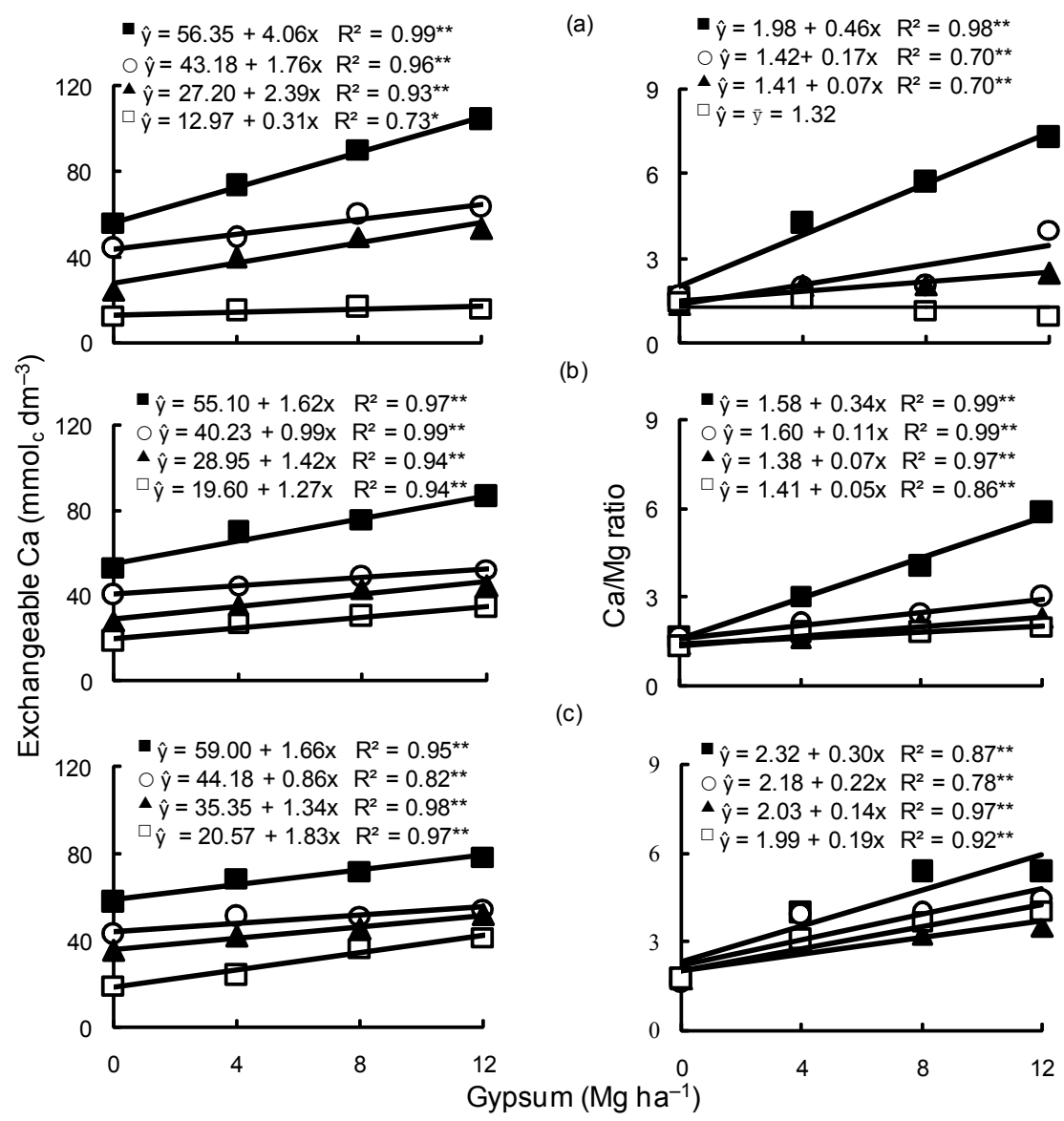

Figure 2 - Changes in $\mathrm{Ca}$ exchangeable and $\mathrm{Ca} / \mathrm{Mg}$ ratio for different soil depths: $0.0-0.1 \mathrm{~m}(\mathbf{\square}), 0.1-0.2 \mathrm{~m}(\mathrm{o}), 0.2-0.4 \mathrm{~m}(\mathbf{\Delta})$, and $0.4-0.6 \mathrm{~m}(\square)$, at 9 (a), 18 (b), and 30 (c) months after surface application of gypsum under a no-till system. ${ }^{*} p<0.05$ and $* * p<0.01$.

ing soil acidity. However, the leaching of exchangeable $\mathrm{Mg}$ after gypsum application can be beneficial for $\mathrm{Ca}$ and $\mathrm{K}$ plant nutrition and crop yield, when the soils present elevated exchangeable $\mathrm{Mg}$ levels and low $\mathrm{Ca} / \mathrm{Mg}$ ratio in the most superficial layers. An increase in the $\mathrm{Ca} / \mathrm{Mg}$ ratio occurred following a gypsum application due to an increase in exchangeable Ca (Figure 2) followed by reduced levels of $\mathrm{Mg}$ (Figure 3) due to leaching of $\mathrm{MgSO}_{4}{ }^{0}$.

Gypsum rates reduced the exchangeable $\mathrm{K}$ content in the soil at $0.0-0.1 \mathrm{~m}$ depth, after 9 months, at $0.0-$ 0.1 and $0.1-0.2 \mathrm{~m}$ depths, after 18 months, and at $0.0-$ $0.1,0.1-0.2$, and $0.2-0.4 \mathrm{~m}$ depths, after 30 months (Figure 3). The leaching of exchangeable $\mathrm{K}$ after gypsum application in our study occurred during the first nine months and was more accentuated than that observed in other studies carried out under NT (Caires et al., 2002, 2004). This may be because the soil in our study had a high exchangeable $\mathrm{K}$ content and a low acidity level throughout the profile. Even so, the exchangeable $\mathrm{K}$ contents remained at levels higher than $2.5 \mathrm{mmol} \mathrm{dm}^{-3}$ at $0.0-0.1 \mathrm{~m}$ soil depth after gypsum application.

The $\mathrm{S}_{-} \mathrm{SO}_{4}^{2-}$ contents, extracted both with calcium phosphate $\left[\mathrm{Ca}\left(\mathrm{H}_{2} \mathrm{PO}_{4}\right)_{2}\right]$ solution and ammonium acetate in acetic acid $\left(\mathrm{NH}_{4} \mathrm{OAc}\right)$ solution, increased in the soil pro- file at 9, 18, and 30 months after the gypsum application (Figure 4). Great leaching of $\mathrm{S}_{-} \mathrm{SO}_{4}^{2-}$ from gypsum applied was observed along time. The extensive leaching of $\mathrm{S}_{-} \mathrm{SO}_{4}{ }^{2-}$ in the soil may have been caused by the low acidity and high organic carbon content, associated with high $\mathrm{P}$ content, especially in the soil surface layers (Table 1). The lower soil adsorption capacity of $\mathrm{S}^{-\mathrm{SO}_{4}}{ }^{2-}$ in such conditions favors its leaching to subsoil layers. The speed which $\mathrm{S}_{-} \mathrm{SO}_{4}{ }^{2-}$ leaches in the soil might vary according to soil and climate conditions (Camargo and van Raij, 1989; Quaggio et al., 1993; Toma et al., 1999; Caires et al., 2003).

There is a positive linear relationship $(p<0.01)$ between the $\mathrm{S}_{-} \mathrm{SO}_{4}^{2-}$ content in the soil profile $(0.0-0.6 \mathrm{~m})$ extracted with $\mathrm{Ca}\left(\mathrm{H}_{2} \mathrm{PO}_{4}\right)_{2}$ solution $\left(\hat{\mathrm{y}}\right.$, in $\left.\mathrm{mg} \mathrm{dm}{ }^{-3}\right)$ and $\mathrm{NH}_{4} \mathrm{OAc}$ solution $\left(x\right.$, in $\left.\mathrm{mg} \mathrm{dm}{ }^{-3}\right)\left(\hat{\mathrm{y}}=4.92+0.99 x, R^{2}\right.$ $=0.92)$. The $\mathrm{S}_{-} \mathrm{SO}_{4}{ }^{2-}$ content in the soil was slightly higher when extracted with $\mathrm{Ca}\left(\mathrm{H}_{2} \mathrm{PO}_{4}\right)_{2}$ solution than extracted with $\mathrm{NH}_{4} \mathrm{OAc}$ solution. It is important to realize that the soil had high contents of clay and organic carbon (Table 1). The $\mathrm{Ca}\left(\mathrm{H}_{2} \mathrm{PO}_{4}\right)_{2}$ solution extracts more $\mathrm{S}_{-} \mathrm{SO}_{4}{ }^{2-}$ adsorbed to oxides and hydroxides of $\mathrm{Fe}$ and $\mathrm{Al}$ than $\mathrm{S}_{-} \mathrm{SO}_{4}{ }^{2-}$ binding to the soil organic fraction (Fox et al., 1964); furthermore, while the $\mathrm{NH}_{4} \mathrm{OAc}$ solution extracts the soluble $\mathrm{S}_{-} \mathrm{SO}_{4}{ }^{2-}$ adsorbed to oxides and part of 


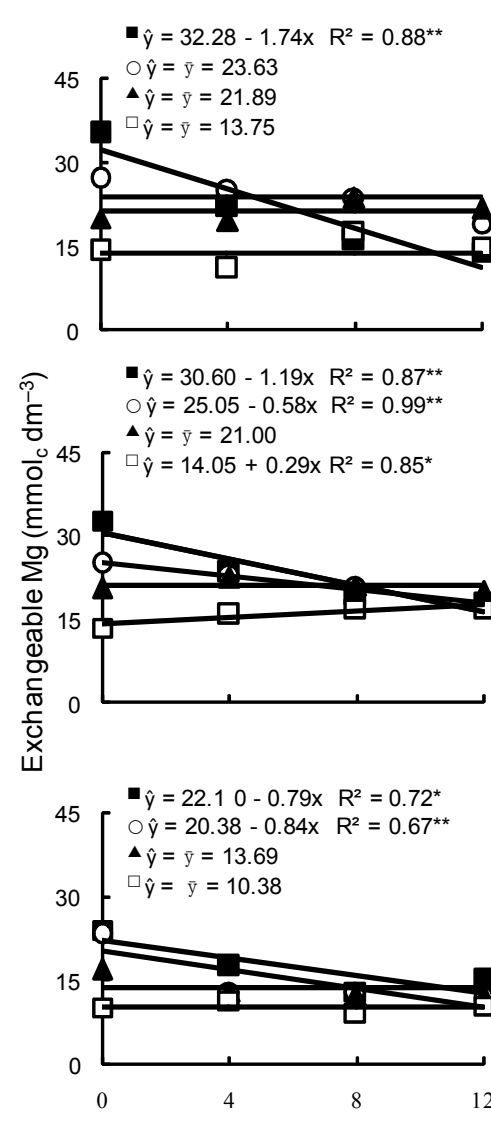

(a)

(b)

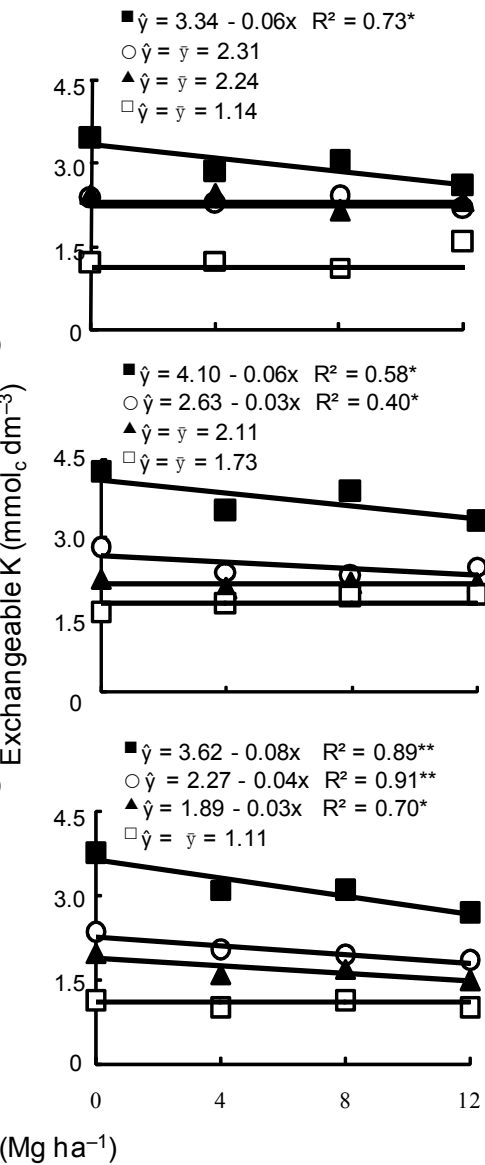

Figure 3 - Changes in exchangeable $\mathrm{Mg}$ and $\mathrm{K}$ for different soil depths: $0.0-0.1 \mathrm{~m}(\boldsymbol{\square}), 0.1-0.2 \mathrm{~m}(\mathrm{o}), 0.2-0.4 \mathrm{~m}(\mathbf{\Delta})$, and 0.4 $-0.6 \mathrm{~m}(\square)$, at 9 (a), 18 (b), and 30 (c) months after surface application of gypsum under a no-till system. ${ }^{*} p<0.05$ and $* * p<0.01$.

the sulfur binding to the soil organic fraction. The extraction of $\mathrm{S}_{-} \mathrm{SO}_{4}^{2-}$ from the soil was slightly higher with the solution of $\mathrm{Ca}\left(\mathrm{H}_{2} \mathrm{PO}_{4}\right)_{2}$ certainly because of the high clay content in the soil. Ribeiro et al. (2001) reported that in soils with high capacity of sulfate adsorption, the sulfur extracted with the $\mathrm{Ca}\left(\mathrm{H}_{2} \mathrm{PO}_{4}\right)_{2}$ solution as well as with the $\mathrm{NH}_{4} \mathrm{OAc}$ solution presented close positive correlation with $\mathrm{S}$ uptake by the plants.

The P content (Mehlich-1) in the $0.0-0.1 \mathrm{~m}$ layer increased linearly with gypsum rates, after 9, 18, and 30 months of the application (Figure 5). Because the precipitation of insoluble calcium phosphates occurs at high soil $\mathrm{pH}$ values (Haynes, 1982), an increase in available Ca did not lead to a decrease in phosphate availability. In our study, besides the soil is acid $\left(\mathrm{pH} 0.01 \mathrm{~mol} \mathrm{~L}^{-1} \mathrm{CaCl}_{2} 5.6-\right.$ 5.8 at $0.0-0.1 \mathrm{~m}$ depth), soil $\mathrm{pH}$ was not affected by gypsum application. Increases in $\mathrm{P}$ content (Mehlich-1) at the $0.00-0.05 \mathrm{~m}$ soil layer in response to gypsum application, were also observed by Caires et al. (2003).

Gypsum rates caused an increase in Ca concentrations in the corn leaves, and in $\mathrm{P}$ and $\mathrm{S}$ concentrations in the corn and soybean leaves (Figure 6). The increase in P and especially $\mathrm{S}$ concentrations in leaves with the applied gypsum rates was higher in the corn than in the soybean. Gyp- sum did not affect $\mathrm{N}, \mathrm{K}$, and $\mathrm{Mg}$ concentrations in the corn and soybean leaves. Increases in $\mathrm{Ca}$ and $\mathrm{S}$ concentrations in corn leaves and in $\mathrm{P}$ and $\mathrm{S}$ concentrations in soybean leaves due to gypsum application under NT systems have been obtained in others studies (Caires et al., 1999, 2003, 2004). As has been shown previously (Sumner et al., 1986; Caires et al., 2003, 2006), the P contained in the gypsum composition as an impurity is important for plant nutrition when high rates of gypsum are applied.

Surface-applied gypsum rates increased quadractically corn grain yield and it did not change grain yields in both soybean crops (Figure 7). According to the adjusted regression equation, the maximum corn yield would be obtained at a rate of $7.8 \mathrm{Mg} \mathrm{ha}{ }^{-1}$ of gypsum, which caused an increase of $11 \%$ in the grain yield. Yield at $12 \mathrm{Mg} \mathrm{ha}^{-1}$ compared to the $8 \mathrm{Mg} \mathrm{ha}^{-1}$ rate was slightly lower likely because of more accentuated leaching of exchangeable $\mathrm{Mg}$ and $\mathrm{K}$ in the soil surface layer (Figure 3). Caires et al. (1999) described an experiment in which the gypsum application increased the yield of corn, but not of soybean, similarly to what was verified in our study. Positive responses to gypsum application on the corn yield were also obtained in several other studies carried out under varied soil and climate (Toma et al., 1999; Farina et al., 2000a; 

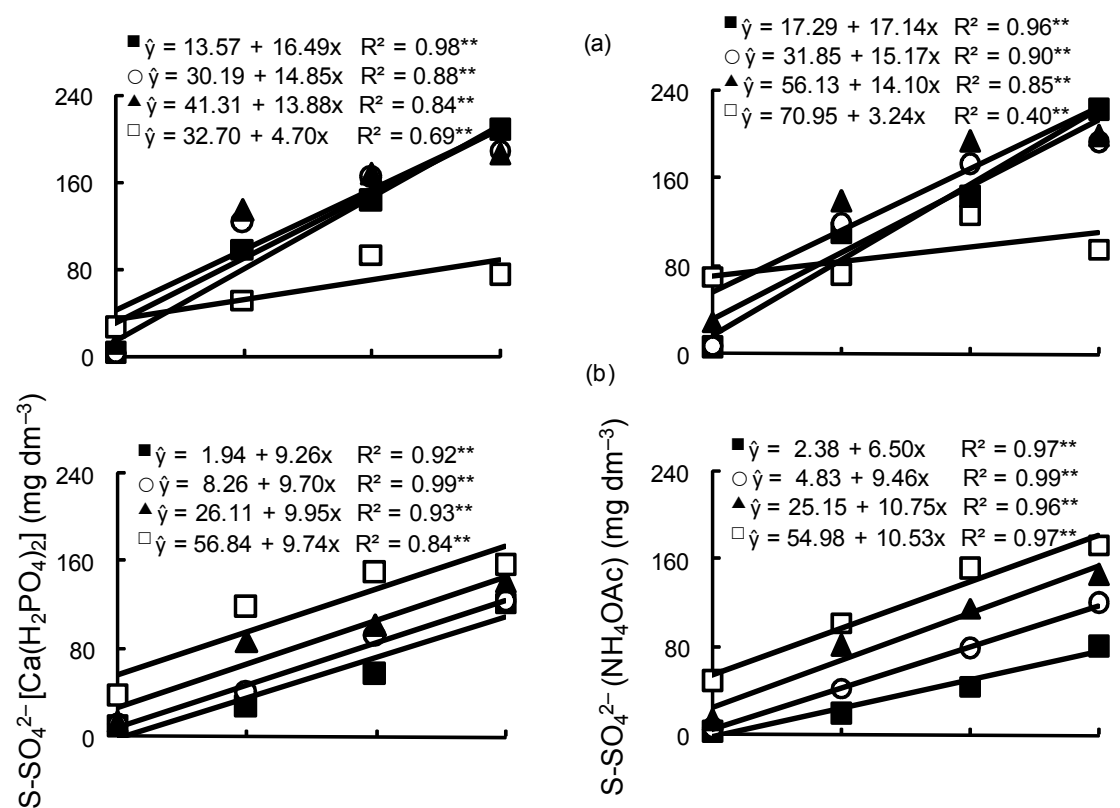

(b)
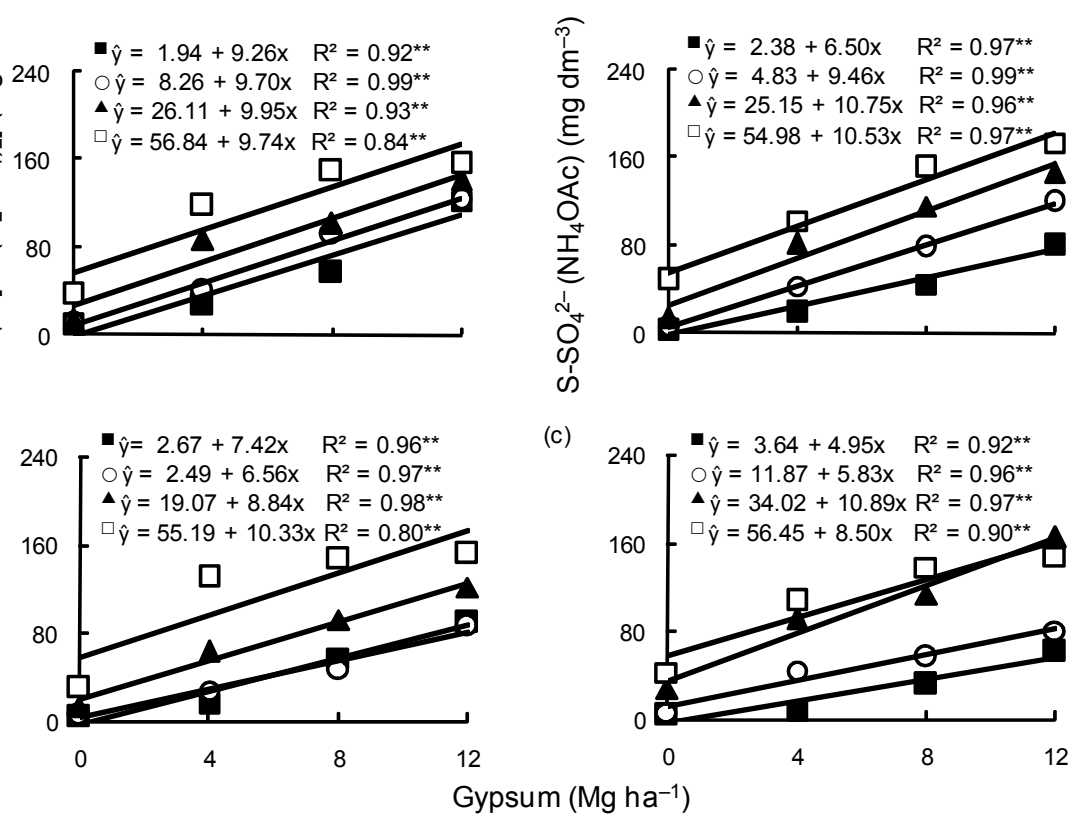

Figure 4 - Changes in S-SO4 $4^{2-}$ extracted with calcium phosphate $0.01 \mathrm{~mol} \mathrm{~L}^{-1}\left[\mathrm{Ca}\left(\mathrm{H}_{2} \mathrm{PO}_{4}\right)\right]$ solution and $0.5 \mathrm{~mol} \mathrm{~L}^{-1}$ ammonium acetate in $0.25 \mathrm{~mol} \mathrm{~L}^{-1}$ acetic acid $\left(\mathrm{NH}_{4} \mathrm{OAc}\right)$ solution, for different soil depths: $0.0-0.1 \mathrm{~m}(\boldsymbol{\square}), 0.1-0.2 \mathrm{~m}(\mathrm{o}), 0.2-0.4 \mathrm{~m}(\mathbf{\Lambda})$, and $0.4-0.6 \mathrm{~m}(\square)$, at 9 (a), 18 (b), and 30 (c) months after surface application of gypsum under a no-till system. $* p<0.05$ and ** $p<0.01$.

(a)

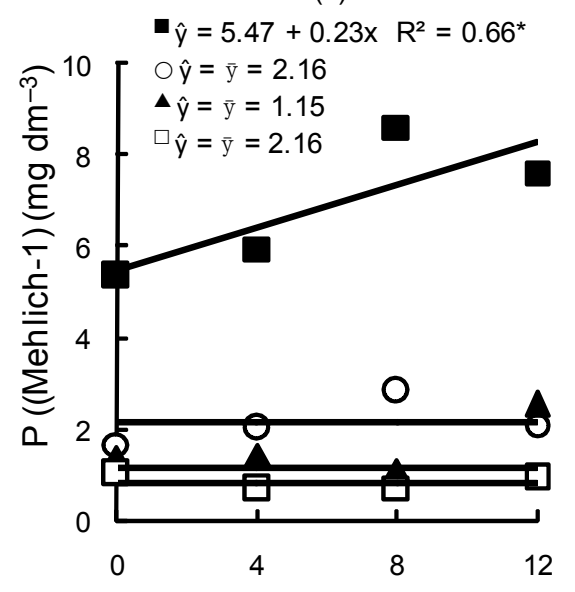

(b)

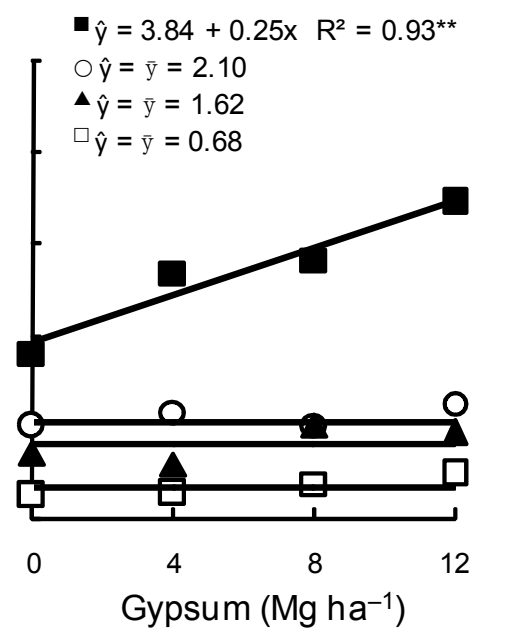

(c)

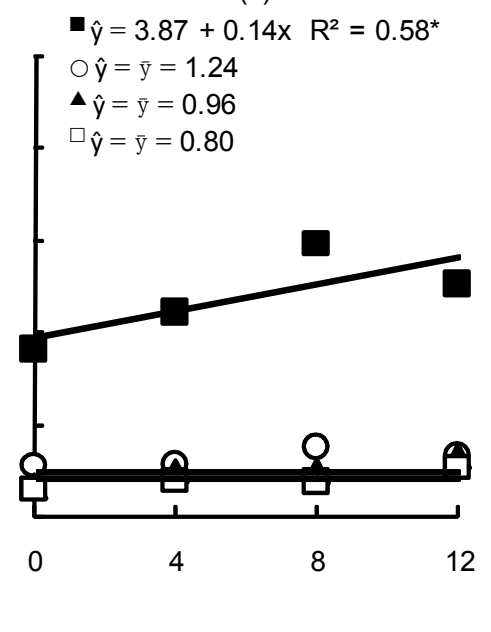

Figure 5 - Changes in P (Mehlich-1) for different soil depths: $0.0-0.1 \mathrm{~m}$ , $0.1-0.2 \mathrm{~m}(\mathrm{o}), 0.2-0.4 \mathrm{~m}(\mathbf{\Delta})$, and $0.4-0.6 \mathrm{~m}(\square)$, at 9 (a), 18 (b), and 30 (c) months after surface application of gypsum under a no-till system. $* p<0.05$ and $* * p<0.01$. 
Caires et al., 2004). In our study, the soil had no exchangeable $\mathrm{Al}$ and had elevated levels of exchangeable $\mathrm{Ca}$ in the subsoil $(0.0-0.6 \mathrm{~m})$, making it unlikely that a yield increase in response to gypsum application was caused by amelioration of subsoil acidity. No response of soybean yield to gypsum (Quaggio et al., 1993; Oliveira and Pavan, 1996; Caires et al., 2003, 2006) has been attributed to the lower Al toxicity to the root growth in NT systems during cropping seasons that have adequate and well-distributed rainfall (Caires et al., 2001, 2008). This reasoning does not apply in this study because the soil did not present chemical limitations for root growth (Table 1).

Based on soil test calibrations, $\mathrm{P}$ content was medium (Figure 5) and S content was low (Figure 4) at 0.0 - $0.1 \mathrm{~m}$ depth in the no gypsum control plots (Oleynik et al., 1998; EMBRAPA, 2005). Because the gypsum rates caused an increase in $\mathrm{P}$ and $\mathrm{S}$ concentrations in the corn and soybean leaves (Figure 6), but they only increased corn grain yield (Figure 7), we can point out that the soybean crop has higher $\mathrm{P}$ and $\mathrm{S}$ uptake efficiency than corn crop. Silva et al. (2003) found different behaviors in $\mathrm{S}$ absorption and redistribution by corn and soybean plants. In spite of having larger root absorption, corn retained great part of that $S$ in the root, while soybean absorbed considerably less, but presented greater translocation efficiency (Silva et al., 2003). In addition, because the gypsum rates increased the Ca concentrations in corn leaves and not in soybean leaves (Figure 6), soybean crop should not be affected by the balance of cations when the exchangeable cations levels in the soil are sufficient. Caires et al. (2004) verified that the increase of corn yield with gypsum application under NT was re-
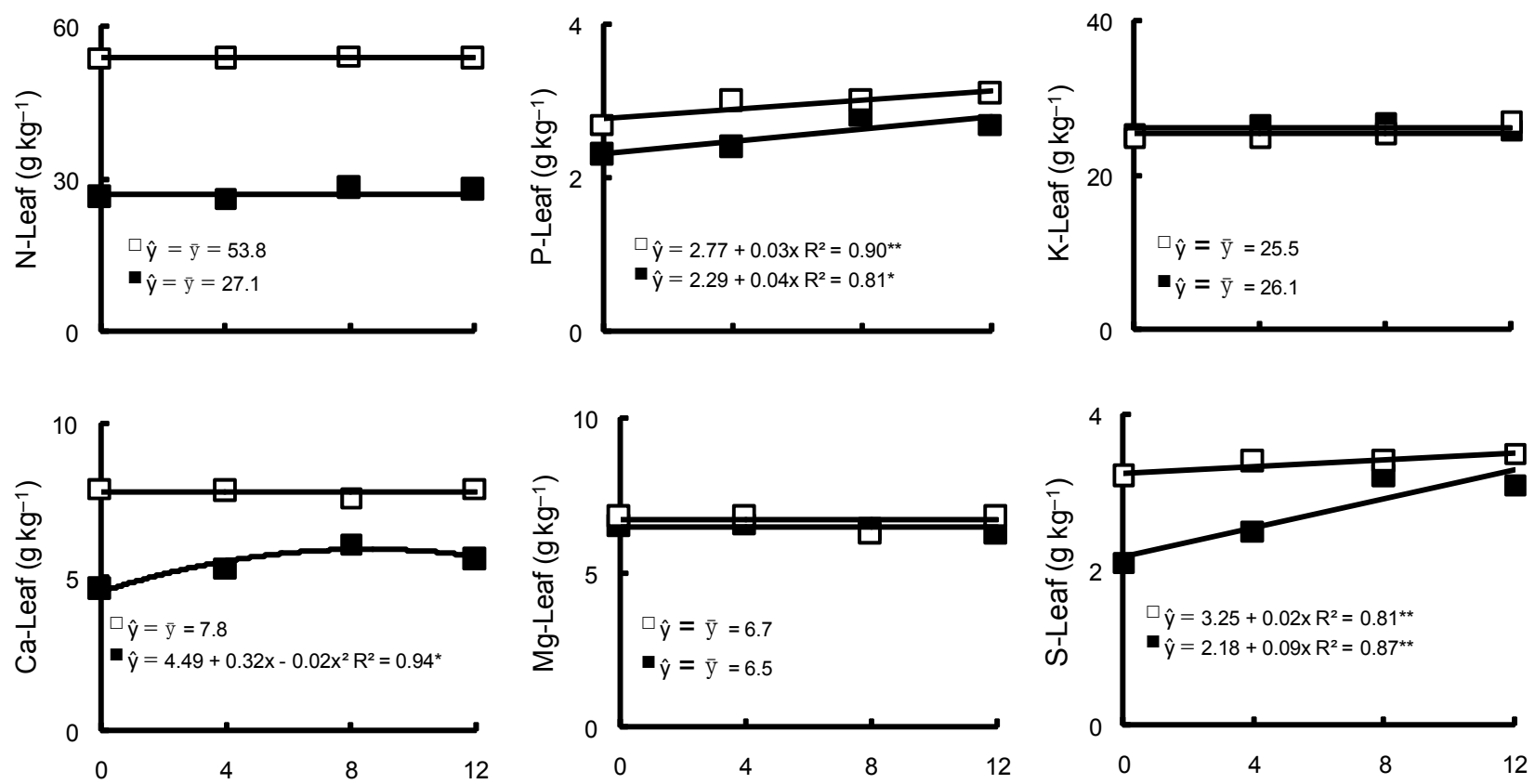

Figure 6 - Nutrient concentrations in leaves of corn grown in 2005-06 (ם) and soybean grown in 2006-07 ( $\square$ ) as affected by surface application of gypsum under a no-till system. ${ }^{*} p<0.05$ and ${ }^{*} p<0.01$.
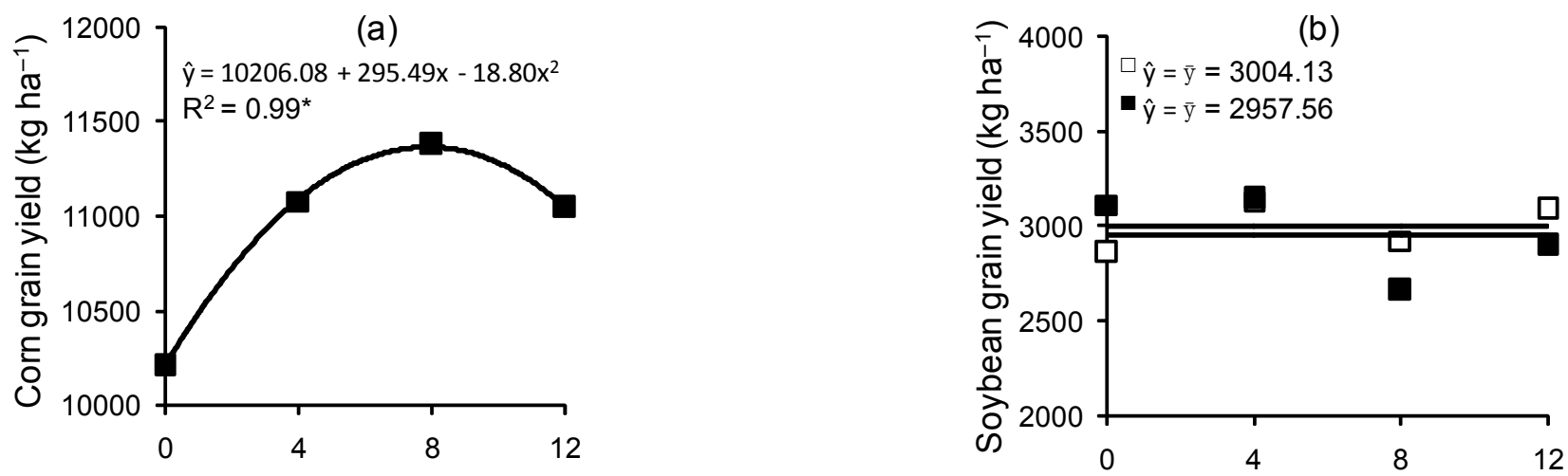

\section{Gypsum (Mg ha-1)}

Figure 7 - Corn in 2005-06 (a) and soybean in 2006-07 ( $\square$ ) and 2007-08 under a no-till system. $*: p<0.05$. 
lated to the increment in $\mathrm{Ca}$ saturation at cation exchange capacity at $\mathrm{pH} 7$ in the soil surface layers. The cation exchange capacity of roots is lower in corn than in soybean (Fernandes and Souza, 2006). Roots having a high charge density tend to accumulate bivalent ions in contrast to roots of low charge density differentially absorbing univalent ions (Wallace and Smith 1955 cited by Broyer and Stout, 1959). So, corn plants are less efficient than soybean plants in $\mathrm{Ca}^{2+}$ uptake from soil solution and an increase in soil exchangeable $\mathrm{Ca}$ content followed by decreased level of exchangeable $\mathrm{Mg}$ with gypsum addition must have favored the $\mathrm{Ca}^{2+}$ uptake by corn plants. The results suggest that gypsum application is an effective practice to improve $\mathrm{P}, \mathrm{Ca}$, and $\mathrm{S}$ nutrition and grain yield of corn in an Oxisol of high fertility and low acidity under a NT.

\section{Acknowledgements}

To CNPq and to CAPES for providing scholarships to the authors.

\section{References}

Broyer, T.C.; Stout, P.R. 1959. The macronutrient elements. Annual Review of Plant Physiology 10: 277-300.

Caires, E.F.; Fonseca, A.F.; Mendes, J.; Chueiri, W.A.; Madruga, E.F. 1999. Corn, wheat and soybean yields as a function of the changes in soil chemical characteristics due to surface application of lime and gypsum under a no-tillage system. Revista Brasileira de Ciência do Solo 23: 315-327. (in Portuguese, with abstract in English).

Caires, E.F.; Fonseca, A.F.; Feldhaus, I.C.; Blum, J. 2001. Root growth and nutrient uptake by soybean as affected by lime and gypsum, under a no-tillage system. Revista Brasileira de Ciência do Solo 25: 1029-1040. (in Portuguese, with abstract in English).

Caires, E.F.; Feldhaus, I.C.; Barth, G.; Garbuio, F.J. 2002. Lime and gypsum application on the wheat crop. Scientia Agricola 59: 357-364.

Caires, E.F.; Blum, J.; Barth, G.; Garbuio, F.J.; Kusman, M.T. 2003. Changes in chemical soil characteristics and soybean response to lime and gypsum applications in a no-tillage system. Revista Brasileira de Ciência do Solo 27: 275-286. (in Portuguese, with abstract in English).

Caires, E.F.; Kusman, M.T.; Barth, G.; Garbuio, F.J.; Padilha, J.M. 2004. Changes in soil chemical properties and corn response to lime and gypsum applications. Revista Brasileira de Ciência do Solo 28: 125-136. (in Portuguese, with abstract in English).

Caires, E.F.; Alleoni, L.R.F.; Cambri, M.A.; Barth, G. 2005. Surface application of lime for crop grain production under a no-till system. Agronomy Journal 97: 791-798.

Caires, E.F.; Churka, S.; Garbuio, F.J.; Ferrari, R.A.; Morgano, M.A. 2006. Soybean yield and quality as a function of lime and gypsum applications. Scientia Agricola 63: 370-379.

Caires, E.F.; Garbuio, F.J., Churka, S.; Barth, G.; Corrêa, J.C.L. 2008. Effects of soil acidity amelioration by surface liming on no-till corn, soybean, and wheat root growth and yield. European Journal of Agronomy 28: 57-64.

Camargo, O.A.; Raij, B. van. 1989. Movement of gypsum in Oxisol samples with different electrochemical properties. Revista Brasileira de Ciência do Solo 13: 275-280. (in Portuguese, with abstract in English).

Cantarella, H.; Prochnow, L.I. 2001. Determination of sulfate in soils. p. 225-230. In: Raij, B. van; Andrade, E.; Cantarella, H.; Quaggio, J.A., eds. Chemical analysis for evaluation on the fertility of tropical soils. Instituto Agronômico, Campinas, SP, Brazil. (in Portuguese).

Carvalho, M.C.S.; Raij, B. van. 1997. Calcium sulphate, phosphogypsum and calcium carbonate in the amelioration of acid subsoils for root growth. Plant and Soil 192: 37-48.

Empresa Brasileira de Pesquisa Agropecuária [EMBRAPA]. 1997. Handbook of Analytical Methods of Soil. 2ed. EMBRAPA- CNPS, Rio de Janeiro, RJ, Brazil. (in Portuguese).
Empresa Brasileira de Pesquisa Agropecuária [EMBRAPA]. 2005. Production Technology of Soybean - Parana 2005. EMBRAPA Soja. Londrina, PR, Brazil. (in Portuguese).

Enani, P.R.; Ribeiro, M.F.S.; Bayer, C. 2004. Chemical modifications caused by 1 iming below the limed layer in a predominantly variable charge acid soil. Communications in Soil Science and Plant Analysis 35: 889-901.

Farina, M.P.W.; Channon, P.; Thibaud, G.R. 2000a. A comparison of strategies for ameliorating subsoil acidity. I. Long-term growth effects. Soil Science Society of America Journal 64: 646-651.

Farina, M.P.W.; Channon, P.; Thibaud, G.R. 2000b. A comparison of strategies for ameliorating subsoil acidity. II. Long-term soil effects. Soil Science Society of America Journal 64: 652-658.

Fernandes, M.S.; Souza, S.R. 2006. Nutrient uptake. p. 115-153. In: Fernandes, M.S., ed. Mineral nutrition of plants. Sociedade Brasileira de Ciência do Solo, Viçosa, MG, Brazil. (in Portuguese).

Fox, R.L.; Olson, R.A.; Rhoades, H.F. 1964. Evaluating the sulfur status of soil by plant and soil test. Soil Science Society of America Proceedings 28: 243-246.

Hammel, J.E.; Sumner, M.E.; Shahandeh, H. 1985. Effect of physical and chemical profile modification on soybean and corn production. Soil Science Society of America Journal 49: 1508-1511.

Haynes, R.J. 1982. Effects of liming on phosphate availability in acid soils. A critical review. Plant and Soil 68: 289-308.

Malavolta, E.; Vitti, G.C.; Oliveira, S.A. 1997. Evaluation of Nutritional Status of Plants: Principles and Applications. 2ed. Potafos, Piracicaba, SP, Brazil. (in Portuguese).

Oleynik, J.; Bragagnolo, N.; Bublitz, U.; Silva, J.C.C. 1998. Soil Analysis: Tables for Conversion of Analytical Results and Interpretation of Results. 5ed. EMATER, Curitiba, PR, Brazil. (in Portuguese).

Oliveira, E.L.; Pavan, M.A. 1996. Control of soil acidity in no-tillage system for soybean production. Soil \& Tillage Research 38: 47-57.

Pavan, M.A.; Bloch, M.F.; Zempulski, H.C.; Miyazawa, M.; Zocoler, D.C. 1992. Handbook of Soil Chemical Analysis and Quality Control. IAPAR, Londrina, PR, Brazil. (in Portuguese).

Peel, M.C.; Finlayson, B.L.; McMahon, T.A. 2007. Update world map of the Köppen-Geiger climate classification. Hydrology and Earth System Sciences 11: 1633-1644.

Quaggio, J.A.; Raij, B. van; Gallo, P.B.; Mascarenhas, H.A.A. 1993. Soybean responses to lime and gypsum and ion leaching into the soil profile. Pesquisa Agropecuária Brasileira 28: 375-383. (in Portuguese, with abstract in English).

Reeve, N.G.; Sumner, M.E. 1972. Amelioration of subsoil acidity in Natal Oxisols by leaching of surface applied amendments. Agrochemophysica 4: 1-6.

Ribeiro, E.S.; Dias, L.E.; Alvarez, V.H., Mello, J.W.V.; Daniels, W.L. 2001. Dynamics of sulfur fractions in Brazilian soils submitted to consecutive harvest of sorghum. Soil Science Society of America Journal 65: 787-794.

Silva, D.J.; Venegas, V.H.A.; Ruiz, H.A.; Sant'Anna, R. 2003. Translocation and redistribution of sulphur in corn and soybean plants. Pesquisa Agropecuária Brasileira 38: 715-721. (in Portuguese, with abstract in English).

Sumner, M.E.; Shahandeh, H.; Bouton, J.; Hammel, J. 1986. Amelioration of an acid soil profile through deep liming and surface application of gypsum. Soil Science Society of America Journal 50: 1254-1258.

Toma, M.; Sumner, M.E.; Weeks, G.; Saigusa, M. 1999. Long-term effects of gypsum on crop yield and subsoil chemical properties. Soil Science Society of America Journal 63: 891-895.

Vitti, G.C.; Suzuki, J.A. 1978. The determination of sulfur-sulfate by turbidimetric method. UNESP, Jaboticabal, SP, Brazil. (in Portuguese).

Zambrosi, F.C.B.; Alleoni, L.R.F.; Caires, E.F. 2007. Nutrient concentration in soil water extracts and soybean nutrition in response to lime and gypsum applications to an acid Oxisol under no-till system. Nutrient Cycling in Agroecosystem 79: 169-179.

Received December 10, 2009

Accepted August 03, 2010 